\title{
KONSEP PENDIDIKAN ISLAM MENURUT IBNU SINA DAN IBNU QAYYIM AL JAUZIYYAH
}

\author{
Ansari \& Ahmad Qomarudin \\ UIN Sunan Kalijaga Yogyakarta \\ ansarisanusin212@gmail.com, ahmadqomarudin707@gmail.com
}

\begin{abstract}
This study aims to describe the concept of Islamic education thought by Ibn Sina and Ibn Qayyim Al-Jauriyyah. The development of Islamic education thinking is important to improve and develop the quality of Islamic education in schools so that they can compete at the international level. The research method is descriptive qualitative and the data collection technique is a library study. The results of this study illustrate that there are fundamental differences from the concept of Islamic education thought both initiated by Ibn Sina and Ibn Qayyim, Ibn Sina's own thoughts are more inclined to the application of knowledge that is adapted to the age level of the child, while Ibn Qayyim's thinking is more inclined to inculcating values of faith and the use of reason to develop children's thinking horizons. However, the thoughts of the two Muslim figures can still be used as a relevant reference in developing Islamic education in Muslim countries around the world, one of which is in Indonesia.
\end{abstract}

Keywords: Islamic Education Concept, Ibn Sina, Ibn Qayyim

\begin{abstract}
Abstrak : Penelitian ini bertujuan mendeskripsikan tentang konsep pemikiran pendidikan Islam oleh Ibnu Sina dan Ibnu Qayyim Al-Jauziyyah. Pengembangan pemikiran pendidikan Islam penting dilakukan guna meningkatkan serta mengembangkan mutu pendidikan Islam di sekolah sehingga dapat bersaing pada level internasional. Adapun metode penelitian yakni deskriptif kualitatif serta Teknik pengumpulan datanya adalah studi Pustakaan. Adapun hasil penelitian ini menggambarkan adanya perbedaan yang mendasar dari konsep pemikiran pendidikan Islam baik yang di gagas oleh Ibnu Sina maupun Ibnu Qayyim, pemikiran Ibnu Sina sendiri lebih condong pada penerapan ilmu pengetahuan yang disesuaikan dengan tingkat umur anak, sedangkan pemikiran Ibnu Qayyim lebih cenderung kepada penanaman nilai-nilai keimanan serta penggunaan akal untuk mengembangkan cakrawala berpikir anak. Namun demikian, pemikiran dari kedua tokoh Muslim tersebut masih bisa dijadikan sebagai acuan yang relevan dalam mengembangkan pendidikan Islam di negara-negara Muslim di seluruh dunia, salah satunya di Indonesia.
\end{abstract}

Kata Kunci: Konsep Pendidikan Islam, Ibnu Sina, Ibnu Qayyim

Volume 3, Nomor 2, Juli 2021; 134-148

https:// ejournal.stitpn.ac.id/index.php/islamika 


\section{PENDAHULUAN}

Di Indonesia sendiri perkembangan pendidikan Islam masih sangat minim, dikarenakan kurangnya perhatian dari pemerintah untuk menjadikan pendidikan Islam sebagai prioritas utama, padahal pendidikan Islam sendiri sangat penting di pelajari oleh peserta didik, supaya bisa meningkatkan kualitas Insani yang beriman dan bertaqwa. Sehingga nantinya bisa menciptakan manusia yang unggul di bidang agama, walaupun nantinya pekerjaan yang mereka tekuni berbeda-beda. Pendidikan Islam sendiri hanya sekedar mentransferkan nilai-nilai normative. Akibatnya, pendidikan Islam akan sulit menerima pembaharuan. Padahal tidak semua yang berkaitan dengan pembaharuan itu negative, banyak juga pembaharuan yang positif. ${ }^{1}$

Pada awal abad ke 7 sampai 12 Masehi, hampir semua ilmu pengetahuan di kuasai oleh para cendikiawan muslim, itu dikarenakan pada saat itu orang-orang muslim berlomba-lomba untuk mempelajari berbagai bidang ilmu, bukan saja ilmu yang berkaitan dengan Islam saja yang mereka pelajari, namun lebih luas dari pada itu, mereka mempelajari ilmu-ilmu yang dikaji oleh orang-orang barat, mereka melakkukan itu semua demi bisa menyaingi, bahkan melampui orang-orang barat dalam hal kecerdasan ilmu pengetahuan. ${ }^{2}$

Banyak para cendikiawan muslim yang pemikirannya masih tetap bertahan sampai saat ini, diantaranya adalah Ibnu Sina dan Ibnu Qayyim, pemikiran mereka berdua bukan saja mengguncangkan dunia pendidikan Islam, namun dunia pendidikan barat pun mereka mampu kuasai. Sehingga orang-orang barat memberikan gelar kepada Ibnu Sina sebagai "The greatest Muslim thnker and the last of the Muslim philoshopher in the East", yang berarti Pemikir Muslim terbesar dan seorang filosof Muslim terakhir dari Timur.

Untuk saya mengangkat penelitian ini, guna membuka cakrawala berpikir umat Islam di dunia, terutama di Indonesia bahwa masih banyak tokoh-tokoh Islam dahulu yang mampu bersaing dengan ilmuwan barat dalam hal ilmu pengetahuan, bahkan

\footnotetext{
${ }^{1}$ Maidar Darwis, Konsep Pendidikan Islam dalam Perspektif Ibnu Sina, (Jurnal: Didaktika, 2013).

2 Abu Muhammad Iqbal, Pemikiran Pendidikan Islam, (Yogyakarta: Pustaka Pelajar, 2015), cet. Ke-1, hal. 1.
} 
ilmuwan Islam dijadikan rujukan oleh orang-orang barat dalam mempelajari berbagai bidang ilmu.

\section{METODE}

Penelitian ini menggunakan metode deskriptif kualitatif, yaitu metode yang digunakan untuk memperoleh pemahaman masalah yang mendalam. manusia dan sosial, tidak menggambarkan permukaan realitas seperti yang dilakukan penelitian kuantitatif dengan positivisme. ${ }^{3}$

Sedangkan teknik pengumpulan datanya adalah penelitian kepustakaan, yaitu dengan mengumpulkan buku-buku dan jurnal-jurnal yang relevan dengan topik yang dibahas. Teknik analisis data menggunakan metode interpretasi. Metode interpretasi adalah metode untuk menemukan dan mengungkapkan makna yang terkandung dalam objek penelitian. Penulis mengumpulkan data dengan cara dokumentasi. Yaitu dengan mengumpulkan buku-buku sebagai bahan bacaan dari berbagai sumber.

\section{HASIL DAN PEMBAHASAN}

\section{Biografi Singkat Ibnu Sina dan Ibnu Qayyim Al-Jauziyyah}

\section{a. Biografi Ibnu Sina}

Ibnu Sina sendiri memiliki nama yang begitu panjang, yaitu "Abu 'Ali alHusain bin Abdullah bin Hasan bin ali bin Sina”. Ia dilahirkan pada sebuah kota kecil bernama Afshana di samping wilayah Bukhara Uzbekistan pada periode 370 H/980 M, Ibnu Sina sendiri memiliki keluarga yang lengkap dan penganut Syiah Isma'illiyah yang taat. Ia memiliki seorang ayah bernama Abdullah dan seorang ibu bernama Astarah. ${ }^{4}$

Di masa kecilnya ia mulai mempelajari Al-Qur'an pada usia sekitar 5 tahun dan berkat kecerdasannya di atas rata-rata sebelum ia mencapai usia 10 tahun ia telah menghafal berbagai macam ilmu antara lain Al-Qur'an, tafsir, fiqh dan lain-

\footnotetext{
${ }^{3}$ Putri Andrika. Konsep Zubud dalam Pandangan al-Gazali dan Konsep Zubud dalam Pandangan Hamka. Tesis UIN Suka Yogyakarta 2020.

${ }^{4}$ Abu Muhammad Iqbal, Pemikiran Pendidikan Islam, hal. 2.
} 
lain. ${ }^{5}$ Ia sendiri memiliki seorang guru bernama "Abu 'Abd Allah al-Natili dan Abi Muhammad Isma'il ibn al-Husyain". 6 Ibnu Sina meninggal dalam rentang umur 58 tahun, sekitar tahun 980 H/1037 M di Hamadan, Iran, karena memiliki riwayat penyakit maag kronis. Sama seperti dia mengajar di sekolah, dia menghembuskan nafas terakhirnya. ${ }^{7}$

\section{b. Karya-Karya Ibnu Sina}

Semasa hidupnya, Ibnu Sina adalah seorang tokoh muslim yang berguna dicatat sebagai buku hard copy untuk dijadikan referensi oleh umat Islam pada masanya, hal ini dilakukan dengan tujuan agar para peneliti muslim niscaya dapat menemukan referensi informasi yang sedang mereka teliti. Sudah tak terhitung lagi banyaknya karya yang berasal dari beliau, ada sekitar 250 macam karya yang telah diciptakan oleh Ibnu Sina. Di antaranya yang sangat terkenal di kalangan peneliti Muslim adalah; Al-Syifa, Al-Najat, Al-Qanun fi al-Thibb, dan Al-Ikode wa al-Tanbihat. ${ }^{8}$

\section{c. Biografi Ibnu Qayyim Al-Jauziyyah}

Ibnu Qayyim memiliki nama yang sangat panjang, tepatnya "Muhammad bin Abi Bakr bin Ayyub bin Sa'ad bin Haris Az-Zar'I Damasqy". Dia dilahirkan pada tahun 691 H/1292 M di kota Hauran, dan meninggal pada 13 Rajab 751 H/1350 M. Ayahnya bernama Abu Bakar, beliau dikenal sebagai peneliti yang luar biasa pada masanya, beliau mendirikan Madrasah "Al-Jauziyyat" di kota Suriah, Damaskus. Dari sini, awal mula beliau dikenal sebagai Ibn Qayyim AlJauziyyat. Dalam mempelajari ilmu Ibnu Qayyim banyak belajar kepada gurugurunya salah satunya yang paling terkenal adalah Ibnu Taimiyyah.

\section{d. Karya-karya Ibnu Qayyim Al-Jauziyyah}

Selama hidupnya, Ibn Qayyim Al-Jauziyah banyak menghasilkan berbagai disiplin ilmu untuk digunakan sebagai sumber perspektif oleh para peneliti muda Muslim di seluruh dunia ini, banyak bukunya terkenal di kalangan peneliti

${ }^{5}$ Safrudin Aziz, Pemikiran Pendidikan Islam, (Yogyakarta: Kalimedia, 2015), cet. Ke-1, hal 82.

${ }^{6}$ Abu Muhammad Iqbal, Pemikiran Pendidikan Islam........., hal. 4

${ }^{7}$ Ibid, hal. 4

${ }^{8}$ Ibid, hal. 4 
Muslim yang dimanfaatkan sebagai bahan pembicaraan atau hanya untuk dipersepsikan, antara lain; Tuhfat al-Maudud bi Abkami al-Maulud, Miftah Daris Sa'adah, A'lam al-Muwaqqi'in 'A Rabbi al-'Alamin, Al-Jawab al-Kafi Liman Sa'ala 'an iklan Dawa'I as - Syafii, dan 'Uddatu Shabirin wa Drakhiratu as-Syakirin al-Salafiyah. juga, sejumlah besar bukunya yang berbeda beredar di seluruh dunia ini.

\section{Pemikiran Pendidikan Islam Ibnu Sina dan Ibnu Qayyim Al-Jauziyyah}

\section{a) Pemikiran Ibnu Sina}

1) Tujuan Pendidikan

Ibnu Sina menjelaskan bahwa tujuan pendidikan memiliki tiga kapasitas, yang semuanya mengatur. Pertama, memutuskan arah dari interaksi instruktif. Kedua, tujuan menentukan arah yang direncanakan serta memberikan perbaikan. Ketiga, tujuannya adalah penghargaan, dan jika dianggap penting, dan kapan pun diinginkan, pasti akan mendorong siswa untuk menggunakan energi yang diharapkan untuk mencapainya. Tujuan memiliki maksud untuk menjadi dasar dalam menjalani interaksi instruktif. ${ }^{9}$

Menarik dari pandangan ini, Ibnu Sina berpendapat bahwa tujuan pendidikan adalah pendidikan harus ditujukan untuk mengembangkan semua potensi yang dimiliki seseorang, khususnya peningkatan fisik, ilmiah dan karakter. Juga, alasan pendidikan seperti yang ditunjukkan oleh Ibnu Sina harus ditujukan pada upaya untuk membentuk seseorang dengan tujuan agar mereka dapat hidup bersama di mata publik dengan menyelesaikan pekerjaan atau kemampuan yang mereka pilih sesuai dengan bakat, minat, kecenderungan dan potensi. ${ }^{10}$

Secara eksplisit mengenai tujuan pendidikan untuk membingkai individu dengan karakter yang mulia, Ibnu Sina juga mengungkapkan bahwa proporsi karakter mulia digambarkan secara luas yang mencakup semua bagian dari keberadaan manusia. Bagian dari kehidupan yang merupakan prasyarat untuk pengakuan individu dengan karakter mulia menggabungkan

${ }^{9}$ Astuti Budi Handayani, Relevansi Konsep Akal Bertingkat Ibnu Sina dalam Pendidikan Islam di Era Milenial, (Jurnal: Ta'dibuna, 2019).

${ }^{10}$ Syamsul Kurniawan, Pemikiran Pendidikan Islam, (Yogyakarta: AR-RUZZ MEDIA, 2013), cet. 2, hal 77. 
sudut pandang individu, sosial dan mendalam. Masing-masing dari ketiganya harus bekerja dengan cara yang esensial dan menjangkau jauh. Penataan akhlak mulia juga bertujuan untuk mencapai kebahagiaan ( $\left.s a^{\prime} a d a b\right)$. Seperti yang ditunjukkan oleh Ibnu Sina, kegembiraan dapat diperoleh orang secara terus menerus. Dari alasan sekolah yang diidentikkan dengan karakter, keahlian, dan kebutuhan akan kemampuan sesuai bakat dan minat, jelas sangat diidentikkan dengan kemajuan jiwa seseorang. Hal ini menunjukkan bahwa tujuan pelatihan mendalam semakin ditekankan. ${ }^{11}$

\section{2) Kurikulum}

Kurikulum pada prinsipnya adalah program instruktif yang berisi berbagai mata pelajaran yang diatur secara efisien serta program latihan yang diperlukan sebagai syarat untuk menyelesaikan program pembelajaran tertentu yang dikemas dalam latihan rencana pendidikan (intra kurikuler). latihan penggabungan program pendidikan (latihan ko-kurikuler). program pendidikan), dan latihan program luar pendidikan (ekstrakurikuler) untuk mencapai tujuan pendidikan.

Ibnu Sina juga merinci beberapa pelajaran yang perlu dipelajari dan dikuasai siswa. Abuddin Nata berpendapat bahwa definisi program pendidikan Ibnu Sina tergantung pada peningkatan usia siswa yang adil dan merata, khususnya: ${ }^{12}$

Pertama, Usia 3-5 tahun. Menurut Ibnu Sina, pada usia ini siswa harus diberikan mata pelajaran olahraga, budi pekerti, kerapian, suara dan keterampilan.

Kedua, Usia 6-14 tahun. Menurut Ibnu Sina, program pendidikan untuk anak usia 6-14 tahun meliputi membaca dan menghafal Al-Qur'an, pelajaran syar'i, dan pelajaran olahraga.

Ketiga, Usia 14 tahun ke atas. Pada usia 14 tahun ke atas, Ibnu Sina melihat mata pelajaran yang harus diberikan kepada anak-anak adalah unik

11 Abu Muhammad Iqbal, Pemikiran Pendidikan Islam........., hal. 7.

12 Abu Muhammad Iqbal, Pemikiran Pendidikan Islam........., hal. 8. 
dalam kaitannya dengan usia masa lalu. Ada banyak mata pelajaran yang bisa diberikan kepada anak usia 14 tahun ke atas. Meskipun demikian, pelajaran ini harus dipilih sesuai dengan kemampuan dan minat anak muda. Hal ini menunjukkan perlunya pemikiran dengan persiapan siswa. Dengan demikian, anak akan memiliki persiapan untuk melakukan belajar dengan baik. $^{13}$

\section{3) Metode Pembelajaran}

Ibnu Sina juga memiliki beberapa ide tentang strategi pembelajaran. Pada dasarnya teknik pembelajaran yang ia tawarkan memiliki perbedaan antara satu materi dengan materi lainnya. Artinya, pemilihan strategi harus mempertimbangkan dari setiap topik pembelajaran, sambil juga mempertimbangkan tingkat formatif/mental siswa. Hal ini terlihat dari beberapa teknik yang ditawarkannya. ${ }^{14}$ Seperti yang ditunjukkan oleh Abuddin Nata, di antara teknik yang ditawarkan oleh Ibnu Sina adalah strategi untuk talqin, menunjukkan, penyesuaian dan model, percakapan, diskusi dan tugas. Ketujuh strategi pembelajaran ini akan dijelaskan di bawah, selain strategi targhib. ${ }^{15}$

Pertama, Strategi Talqin, harus digunakan dalam menunjukkan bacaan Al-Qur'an, dimulai dengan mendengarkan bacaan Al-Qur'an kepada siswa, bagian demi bagian. Kemudian anak itu didekati untuk mendengarkan dan mengulangi bacaannya secara bertahap dan berulang-ulang, sampai akhirnya dia mempertahankannya.

Kedua, Teknik Menampilkan (Demonstrasi), dapat dimanfaatkan dalam pembelajaran fungsional, seperti cara mengajar mengarang. Menurut Ibnu Sina, jika seorang pendidik akan menggunakan strategi ini, ia harus terlebih dahulu memberikan ilustrasi menulis huruf hijaiyah sebelum muridnya. Sejak saat itu, mintalah siswa untuk mendengarkan kata-kata dari huruf hijaiyah sesuai dengan makhraj nya.

${ }^{13}$ Ibid, hal. 10

${ }^{14}$ Ibid, hal. 11.

15 Ibid, hal. 11. 
Ketiga, teknik penyesuaian dan terpuji, termasuk mungkin strategi pertunjukan terbaik, khususnya dalam mengajarkan etika. Strategi ini pada umumnya dilakukan dengan penyesuaian dan model yang disesuaikan dengan peningkatan semangat anak. Ibnu Sina menyadari dampak "mengikuti atau meniru" atau model asli dalam siklus pendidikan di kalangan anak-anak di usia dini pada kehidupan mereka, dengan alasan bahwa dalam tabi'iyah anak-anak cenderung mengikuti dan meniru-meniru semua yang mereka lihat, rasakan dan dengar.

Keempat, Teknik Percakapan (Diskusi), harus dimungkinkan dengan memperkenalkan latihan di mana siswa dihadapkan pada pertanyaan yang sulit dipecahkan oleh siswa itu sendiri, maka untuk itu dibicarakan dan ditangani bersama. Ibn Sina menggunakan strategi ini untuk menunjukkan informasi yang objektif dan hipotetis. Informasi tentang model ini pada masa Ibnu Sina berkembang pesat. Jika informasi diajarkan dengan teknik bicara, para siswa tertinggal jauh dari kemajuan ilmu pengetahuan.

Kelima, Strategi Magang, Ibnu Sina telah memanfaatkan teknik ini dalam latihan mendidiknya. Murid-murid Ibnu Sina yang meneliti pengobatan didorong untuk menggabungkan hipotesis dan praktik. Strategi ini akan memiliki keuntungan ganda, lebih spesifik dan membuat siswa mampu di bidang ilmu pengetahuan, juga akan memperoleh keterampilan kerja yang menghasilkan uang.

Keenam, Strategi Tugas, diakhiri dengan memesan berbagai modul atau skrip dan kemudian menyerahkannya kepada siswa untuk dipertimbangkan. Teknik ini ia lakukan, antara lain, ia lakukan kepada salah satu muridnya yaitu Abu ar-Raihan al-Biruni dan Abi Husain Ahmad asSuhaili. Dalam bahasa Arab, mengajar dengan tugas ini dikenal dengan alta'lim bi al-marasil (mendidik dengan mengirimkan berbagai tulisan atau modul).

Ketujuh, Teknik Targhib, dalam pengajaran saat ini istilah penghargaan diwujudkan yang menyiratkan hadiah, hadiah, hibah atau hadiah dan 
merupakan salah satu perangkat edukatif dan sebagai umpan balik yang membangkitkan semangat, serta inspirasi yang luar biasa.

Dari sebagian teknik yang digambarkan di atas, terlihat bahwa Ibnu Sina berkonsentrasi pada pelatihan. Dalam setiap peristiwa ada empat atribut teknik yang ditawarkan oleh Ibnu Sina, khususnya: (1). Pemilihan dan pemanfaatan teknik harus disesuaikan dengan kualitas topik, (2). Strategi tersebut juga diterapkan dengan memikirkan ilmu otak para siswa, termasuk kemampuan dan minat anak-anak, (3). Teknik yang ditawarkan bukannya tidak fleksibel, namun bisa berubah-ubah sesuai dengan kondisi dan kebutuhan siswa, dan (4). Ketepatan dalam memilih dalam menerapkan strategi akan menentukan pencapaian pembelajaran. ${ }^{16}$

\section{4) Konsep Guru}

Pendidik memiliki tugas vital dalam pengajaran. Ibnu Sina juga tetap berhubungan dengan sebagian pemikirannya tentang ide seorang pengajar, terutama dalam hal seorang pendidik yang baik. Menurut beliau, pendidik yang baik adalah pengajar yang lihai, tegas, paham mengajarkan etika, cakap dalam mendidik anak, berpenampilan menarik, jauh dari cemoohan dan main-main dengan anak didiknya, tidak tajam dalam berkonfrontasi, perhatian, bersih dan murni. ${ }^{17}$

Tugas seorang pendidik dalam mengajar tidaklah sederhana. Karena, pada umumnya, tugas utama pendidik adalah untuk membentuk pergantian peristiwa anak-anak dan membiasakan diri dengan rutinitas yang bermanfaat dan karakteristik yang baik untuk menjadi faktor utama dalam mencapai kegembiraan anak-anak. Oleh karena itu, individu yang diteladani harus menjadi pelopor yang dapat diterima, model sejati dan memiliki karakter agar tidak berdampak buruk pada semangat anak-anak yang menirunya. ${ }^{18}$

Kemudian Ibnu Sina juga menambahkan bahwa seorang pengajar harus menjadi pribadi yang baik dan menonjol dalam karakter, cerdas, intensif,

${ }^{16} \mathrm{Ibid}$, hal. 11.

${ }^{17}$ Syamsul Kurniawan, Pemikiran Pendidikan Islam...., hal 85.

18 Ibid, hal. 85. 
sabar, teliti dalam mengarahkan anak-anak, bijaksana, efektif dalam pemanfaatan waktu, suka hidup berdampingan dengan anak-anak, tidak berbelas kasih dan meningkatkan secara konsisten. Selain itu, pendidik juga harus fokus pada kepentingan individu di atas keuntungan mereka sendiri, bersumpah meniru ide tuan dan individu dengan etika rendah, mengetahui moral dalam jama'ah yang logis, setuju dan sopan dalam berdiskusi, memeriksa dan berbaur.

Gambaran di atas menunjukkan bahwa Ibnu Sina membutuhkan seorang pengajar yang memiliki kemampuan logika yang tinggi, berbudi pekerti luhur dan menawan sehingga ia dianggap dan menjadi simbol bagi murid-muridnya. Ini penting, karena, dalam kasus di mana instruktur tidak memiliki pemahaman yang luas tentang topik yang benar-benar fokus pada orang tersebut dan membutuhkan pesona, siswa tidak akan menyukainya. Dengan asumsi itu terjadi, informasi akan sulit didapat, meski sudah diketahui namun wakafnya jelas berkurang. ${ }^{19}$

5) Konsep Hukuman dalam Pengajaran

Ibnu Sina pada dasarnya tidak suka menggunakan disiplin dalam mendidik. Hal ini ditunjukan pada wataknya yang benar-benar menghargai kemuliaan manusia. Namun dalam keadaan terpaksa, disiplin dapat dilakukan dengan hati-hati. Ibnu Sina memahami bahwa manusia memiliki indra yang selalu perlu dipuja, tidak mau diperlakukan kasar, dan suka diperlakukan dengan lembut. Berdasarkan pandangan filantropis ini, Ibnu Sina secara serius membatasi pelaksanaan disiplin. Pemanfaatan uluran tangan merupakan mitra yang paling dapat diandalkan dan merupakan keahlian bagi guru. Dengan kontrol terus-menerus, mengajar anak-anak dapat dikelola dan dikoordinasikan sesuai tujuan instruktif. ${ }^{20}$

Ibnu Sina mengizinkan pelaksanaan disiplin dengan cara yang ekstra hati-hati, dan itu harus dilakukan dalam kondisi yang terbatas. Sedangkan dalam kondisi biasa, pendisiplinan tidak boleh dilakukan. Dikarenakan Sikap

19 Abu Muhammad Iqbal, Pemikiran Pendidikan Islam......, hal. 14.

${ }^{20}$ Syamsul Kurniawan, Pemikiran Pendidikan Islam,... hal 86. 
humanistik ini terutama sesuai dengan gagasan pemerintahan rakyat yang menuntut pemerataan, kemanusiaan, keadilan, dan lain-lain. ${ }^{21}$

\section{b) Pemikiran Ibnu Qayyim Al-Jauziyyat}

1. Tujuan pendidikan

Sebagaimana ditunjukkan oleh Ibn Qayyim bahwa tujuan pendidikan Islam adalah untuk menjaga kualitas nilai manusia (fitrab) dari segala kesenjangan agar tidak terjerumus ke dalam lembah dosa, selain untuk konsisten menjadi hamba yang konsisten bersyukur kepada Allah SWT'.

Pada umumnya, Ibn Qayyim membagi beberapa target dalam pendidikan Islam, khususnya:

Pertama, Abdaf Jismiyah (tujuan yang diidentikkan dengan tubuh) yaitu untuk menjaga dan melatih siswa agar tubuh mereka selalu kokoh. Hal ini sesuai dengan apa yang diinstruksikan oleh Ibnu Qayyim Al-Jauziyyat kepada para walinya "Setiap bayi di dunia ini harus benar-benar diperhatikan oleh orang lain, mengingat susu yang dihasilkan oleh ibu yang baru saja melahirkan bayi. selama satu sampai tiga hari masih belum steril dan terlalu keras untuk dimakan anak karena cenderung tidak aman bagi tubuh anak itu sendiri.

Kedua, Abdaf Akblakiyah (diidentikkan dengan pendidikan akhlak) sebagaimana ditunjukkan oleh Ibn Qayyim, dengan akhlak yang baik, seseorang akan mencapai kepuasan yang hakiki dan menjauhi akhlak yang buruk. Selain itu, Ibnu Qayyim menghimbau kepada para pengajar (murabbi) untuk secara konsisten memberikan bimbingan kepada siswa, agar mereka umumnya bersih, jual beli dan tidak berbohong, karena dapat membahayakan jiwa mereka sendiri, sebagaimana ia berpesan kepada para wali yang mendampinginya: mengalami kerusakan jiwanya di dunia dan akhirat jika dia berbohong atau menipu sekali pun, karena ini akan

${ }^{21} \mathrm{Ibid}$, hal. 86 
menggagalkan semua kesopanan yang harus dilakukan seorang anak, jika dia tidak berbohong.

Ketiga, Abdaf Fikriyah (tujuan yang diidentikkan dengan pergantian peristiwa ilmiah) yaitu, pendidikan yang menyeluruh akan melahirkan pertimbangan-pertimbangan yang besar, kemudian lagi, pengajaran yang tidak berdaya akan melahirkan pemikiran-pemikiran yang buruk, dan bagaimanapun juga akan membawa manfaat bagi kemajuan mental anakanak. anak-anak di kemudian hari. Sebagaimana nasehat Ibnu Qayyim kepada para pengajar (murabbi) bahwa "yang tidak dapat disangkal oleh para guru adalah tidak boleh mengizinkan seorang siswa melakukan kegiatan yang dapat membahayakan kesehatan jiwanya, misalnya minuman keras, obat-obatan terlarang, dan sebagainya. membahayakan dan bisa menjatuhkan anak itu ke jurang kebinasaan.

Keempat, Abdaf Maslakiyah (tujuan yang diidentikkan dengan kemampuan), khususnya sekolah harus dapat menumbuhkan kemampuan anak-anak terhadap bakatnya. Selain itu, penting bagi guru untuk mengenali kemampuan, bakat, dan minat agar dengan mudah mengembangkan kemampuan mereka secara maksimal dengan bimbingan dari instruktur. Sebagaimana anjurannya bahwa "hal-hal yang harus diperhatikan dalam pengajaran adalah kemampuan dan bakat yang digerakkan oleh setiap siswa.

2. Kurikulum

Sasaran kurikulum pendidikan yang dirintis oleh Ibnu Qayyim AlJauziyah untuk pendidikan Islam adalah sebagai berikut:

Pertam. Pembinaan Imaniyyah adalah pembelajaranan yang dilakukan oleh guru (murabbi) kepada para siswa terhadap kepercayaan diri agar mencapai puncaknya (ridho Allah SWT).

Kedua. Pengajaran rukbiyyah adalah pendidikan yang dilakukan oleh guru kepada anak-anak dalam mencari tahu tentang jiwa. 
Ketiga. Pengajaran fikriyah adalah gerakan yang dilakukan oleh guru dengan mempersiapkan tenaga dan menciptakan kapasitas keilmuan (daya pikir) dan memperluas cakrawala dan cakrawala nalar anak

Keempat. Pelatihan 'Athifiyyah, adalah sekolah yang merencanakan untuk mengkoordinasikan setiap kata, perbuatan untuk satu tujuan, khususnya kursus yang dimuliakan oleh Allah SWT.

Kelima. Persekolahan khulukiyah adalah mempersiapkan siswanya agar memiliki akhlak mulia dan perilaku yang patut diteladani, agar terbentuk karakter yang kokoh pada diri seorang anak.

Keenam. Sekolah ijtimaiyyah adalah pengajaran yang berupaya untuk mengumpulkan hubungan yang kuat antara individu dengan berfokus pada sensasi orang lain dan menyambut mereka untuk memenuhi orang lain bersama-sama.

Ketujuh. Sekolah iradiyyah (kehendak) bahwa semua yang telah dikehendaki oleh Allah SWT adalah untuk secara konsisten puas dan mencintainya.

Kedelapan. Ajaran badaniyyah adalah usaha yang dilakukan sekolah kepada siswa dalam mendidik tubuh dengan memberinya rezeki, pengobatan dan latihan yang besar.

Kesembilan. Jinsiyyah (Pengajaran Seks) adalah sekolah yang memerintahkan siswa untuk menjauhi penyimpangan seksual. Sehingga mereka terlindung dari perbuatan yang dilarang. ${ }^{22}$

3. Guru (Murabbi)

Menurut Ibn Qayyim Al-Jauziyyat, pendidk adalah seorang yang alim. Sedangkang Rabbani adalah seorang mu'allim, lebih tepatnya seseorang yang memiliki panggilan untuk mengajar orang dengan wawasannya.

Ada beberapa poin yang harus dimiliki oleh pendidik, yakni sebagai berikut: (a). Pendidik harus memiliki sifat zuhud yang hakiki. (b). Memiliki pengetahuan yang layak tentang agama. (c). Perlu mengajak individu ke jalan petunjuk atau kebenaran mendasar, secara konsisten menunjukkan

22 Ibid, hal. 167 
pengekangan dalam memulihkan orang dengan informasi dan Al-Qur'an. (d). Seorang guru harus berhati-hati dalam memberikan ilmunya. (e). memiliki rasa haus akan ilmu pengetahuan. (f). terus berlatih wawasan mereka. (g). guru dianjurkan memiliki rasa (takut kepada Allah). (h). guru harus memiliki gagasan serta kerinduan akan informasi. (i). guru harus memiliki standar dalam mendidik serta dalam pembelajaran.

\section{KESIMPULAN}

Dari uraian pemikiran pendidikan baik yang dilakukan oleh Ibnu Sina maupun Ibnu Qayyim Al-Jauziyyat di atas, dapat disimpulkan pada intinya tujuan pemikiran mereka sama yakni untuk memajukkan pendidikan Islam di negara-negara Muslim di dunia. Namu ada beberapa perbedaan baik itu dari cara berpikirnya, tujuan, metode, maupun klasifikasi yang harus dimiliki oleh tenaga pendidik. Sebagaimana ditunjukkan oleh Ibnu Sina bahwa interaksi edukatif harus diberikan sejak awal hingga dewasa dengan melihat bagian-bagian mental siswa. Setiap tingkatan usia membutuhkan bahan-bahan tertentu yang ditunjukkan oleh tingkat mental/kapasitas anak. Di usia dini, penekanannya ada pada sudut emosional/moral, pada usia muda, berbagai ilmu penting akan disajikan, sementara pada usia dewasa dikoordinasikan dengan keterampilan logis atau tekad sebagai ditunjukkan oleh kemampuan dan minatnya. Sedangkan menurut Ibnu Qayyim Al-Jauziyyat menekankan akan pentingnya pendidikan iman, akal, serta badan. Dengan pendidikan tersebut maka akan menciptakan pribadi yang Bahagia dunia dan akhirat, dan dapat mencegah terjadinya jiwa yang rusak akibat perbuatan yang melenceng dari agama Islam.

Teknik pengajaran perlu diperhatikan bagian mental serta karakter yang miliki oleh masing-masing indiividu peserta didik. Dalam memperkenalkan teknik ini, seorang guru dianjurkan fokus pada pergantian peristiwa moral, baik karakter pendidik itu sendiri misalnya maupun perilaku siswa yang harus dikoordinasikan dengan baik. Karena seorang pendidik tidak hanya dituntut untuk pintar dan terampil di bidangnya, ia juga harus memiliki karakter yang mulia, penuh dengan mistik sehingga ia menjadi contoh dan simbol yang baik bagi murid-muridnya. 
Oleh karena itu, renungan dua tokoh Muslim di atas patut kita telusuri dan patut dijadikan acuan dalam perbaikan pendidikan Islam saat ini. Untuk situasi ini, pertimbangan-pertimbangannya harus diciptakan dan diwujudkan dengan alasan bahwa pertimbangan-pertimbangan tersebut dianggap relevan dengan negara-negara ajaran Islam, khususnya di Indonesia.

\section{DAFTAR PUSTAKA}

Aziz Safrudin, Pemikiran Pendidikan Islam, Yogyakarta: Kalimedia, 2015.

Darwis Maidar, Konsep Pendidikan Islam Dalam Sudut Pandang Ibnu Sina, Diary: Pedantic, 2013.

Iqbal Muhammad Abu, Pemikiran Pemikiran Islam, Yogyakarta: Perpustakaan Mahasiswa, 2015.

Handayani Astuti Budi, Relevansi Konsep Akal Bertingkat Ibnu Sina dalam Pendidikan Islam di Era Milenial, Diary: Ta'dibuna, 2019

Ismail. Dkk. Paradigma Pendidikan Islam, Yogyakarta: Understudy Library, 2011

Kurniawan Syamsul, Pemikiran Pendidikan Islam, Yogyakarta: AR-RUZZ MEDIA, 2013.

Margustam, Filsafat Pendidikan Islam Menuju Pembentukan Karakter, Yogyakarta: Pascasarjana UIN Sunan Kalijaga, 2018.

Syamsi Muhammad, Konsep Pendidikan Islam, Studi Atas Pemikiran Ibn Qayyim AlJanziyyat. Bandung: ATTAQWA, 2018

Nasr Hossein Seyyed, Ensiklopedia Tematis Filsafat Islam, Bandung: Mizan, 2013

Putri Andrika. Konsep Zubud dalam Pandangan al-Gazali dan Konsep Zubud dalam Pandangan Hamza. Tesis UIN Suka Yogyakarta, 2020 